Penelitian

\title{
Kualitas Pakan Ruminansia yang Difermentasi Bakteri Selulolitik Actinobacillus sp.
}

\author{
(Ruminant Feed Quality Fermented by Cellulolytic Bacteria Actinobacillus Sp.) \\ Mohammad Anam Al-Arif, Mirni Lamid \\ Departemen Ilmu Peternakan, Fakultas Kedokteran Hewan, Universitas Airlangga Kampus C \\ Jl. Mulyorejo - Surabaya, 60115. \\ Penulis untuk korespondensi: a_alarif@yahoo.com \\ Diterima 4 Juli 2013, Disetujui 16 September 2013
}

\begin{abstract}
ABSTRAK
Penelitian ini bertujuan untuk mengetahui aktivitas selulolitik bakteri Actinobacillus sp. yang dikembangbiakkan menggunakan media alternatif yang murah. Ransum lengkap disusun kemudian difermentasi menggunakan dua faktor perlakuan meliputi empat dosis fermentasi dan dua masa inkubasi. Dosis fermentasi terdiri dari $0 \%(\mathrm{~K}), 2 \%(\mathrm{~A}), 3,5 \%(\mathrm{~B})$ and $5 \%(\mathrm{C})$, sedangkan faktor inkubasi terdiri dari 3 hari dan 7 hari. Media alternatif menggunakan bahan-bahan kimia teknis yang ditambah dengan susu bubuk dan jerami. Hasil penelitian menunjukkan bahwa dosis A, B dan C yang diinkubasi 7 hari secara signifikan meningkatkan kandungan bahan organik dan protein kasar, serta menurunkan serat kasar. Dosis B dan C dengan waktu inkubasi 7 hari secara signifikan meningkatkan kandungan bahan kering.
\end{abstract}

Kata kunci: bakteri selulolitik, media alternatif, ransum lengkap.

\begin{abstract}
The aim of study is to determine the activity of cellulolytic bacteria Actinobacillus sp. were cultured in a cheap alternative media. A total mix ration fermented using two factors that include four doses of fermentation and two incubation periods. The doses of fermentation consists of $0 \%(K), 2 \%(A), 3.5 \%(B)$ and $5 \%(C)$, whereas incubation factor consists of 3 days and 7 days. Alternative media using technical chemicals added with milk powder and paddy straw. There indicate that fermentation in $A, B$ and $C$ that incubate in 7 days significantly increase organic matter and crude protein, and significantly decrease crude fiber content of ration. The dose of $B$ and $C$ that incubate in 7 days significantly increase dry matter content.
\end{abstract}

Key words: cellulolytic bacteria, alternative media, total mix ration.

\section{PENDAHULUAN}

Hijauan merupakan bahan pakan utama bagi ternak ruminansia. Kekurangan hijauan pakan ternak setiap tahun, terutama pada musim kemarau, merupakan masalah yang harus di atasi. Pemanfaatan limbah pertanian berupa jerami padi, bekatul, tongkol jagung, tumpi jagung, kulit cokelat, kulit kopi dan lain-lain sebagai pakan ternak diharapkan dapat menjadi solusi dalam masalah tersebut (Makarim et al., 2007). Potensi produksi limbah pertanian cukup tinggi, namun terdapat permasalahan berupa nilai nutrisi yang rendah, yaitu kandungan serat kasar (selulosa dan hemiselulosa) yang tinggi serta

(c) 2014 Fakultas Kedokteran Hewan IPB protein kasar yang rendah. Molekul selulosa dan hemiselulosa sulit dicerna, bahkan dalam waktu 48 jam mikrob rumen hanya dapat menghidrolisis selulosa sebesar 60-65\% (Breznak \& Brune, 1994), oleh sebab itu dibutuhkan pengolahan terlebih dahulu sebelum dikonsumsi ternak.

Dinding sel tanaman umumnya mengandung selulosa, hemiselulosa, lignin, dan silikat, sedangkan selulosa merupakan komponen utama (Lynd et al., 2002). Kandungan selulosa tanaman bisa mencapai 40-45\% (Bhat \& Hazlewood, 2001), 15-40\% (Doi \& Kosugi, 2004), atau 35-50\% (Saha, 2004). Komposisi kimia selulosa sangat sederhana, hanya berupa rangkaian glukosa yang terhubung dengan ikatan http://www.journal.ipb.ac.id/indeks.php/actavetindones 
$\beta$-1,4-glikosida, panjangnya bisa mencapai 10.000 molekul D-glukosa sehingga merupakan sumber energi yang sangat potensial (Yeoman et al., 2010). Pada umumnya, ikatan $\beta$-1,4-glikosida tidak terlalu sulit untuk didegradasi, namun dengan adanya ikatan hidrogen maka selulosa dapat membentuk kristal yang sangat kuat. Untuk mencerna selulosa dibutuhkan enzim selulase yang terdiri atas endoglukanase, eksoglukanase, dan selobiase (Wang, 2004).

Memproduksi enzim selulase membutuhkan biaya yang relatif mahal. Oleh sebab itu, penghematan dalam biaya produksi sangat penting dalam penggunaannya secara komersial (Zhang et al., 2006). Dengan demikian, dibutuhkan suatu media alternatif untuk pertumbuhan bakteri selulolitik dengan menggunakan bahan baku yang murah. Mishra et al. (2007) memproduksi enzim lignoselulase menggunakan lima strain bakteri selulolitik dan empat strain fungi dengan jerami padi sebagai substrat. Qi et al. (2008) berhasil memproduksi enzim selulase menggunakan substrat campuran jerami padi dan dedak gandum menggunakan inokulan Trichoderma viride, sedangkan Singh et al. (2009) memproduksi enzim selulase secara masal dengan harga murah menggunakan substrat jerami padi serta inokulan berupa fungi Aspergillus heteromorphus.

Mirni et al. (2006) telah melakukan isolasi bakteri Actinobacillus sp. yang mampu memproduksi enzim hemiselulase dan selulase. Bakteri tersebut terbukti dapat meningkatkan kualitas jerami padi serta meningkatkan kecernaan pada domba. Al-Arif \& Mirni (2011) menemukan bahwa produksi bakteri Actinobacillus sp. skala masal menggunakan media alternatif berupa mineral teknis dan jerami padi sebagai substrat serta susu bubuk sebagai sumber nitrogen ditemukan aktivitas selulolitik paling tinggi dibandingkan dengan sumber nitrogen lain.

Penelitian ini bertujuan untuk mengetahui efektivitas bakteri Actinobacillus sp. yang dikembangbiakkan menggunakan media alternatif dalam mendegradasi pakan ruminansia, dengan mengukur kandungan bahan kering, bahan organik, protein kasar, dan serat kasar.

\section{BAHAN DAN METODE}

Materi penelitian berupa ransum ruminansia yang terdiri atas: bahan-bahan limbah berupa bungkil kelapa sawit, kopra, slamper, dan dedak padi dalam Media alternatif skala masal terdiri atas $\mathrm{MgSO}_{4}, \mathrm{Na}_{2} \mathrm{HPO}_{4}, \mathrm{NH}_{2} \mathrm{SO}_{4}, \mathrm{KH}_{2} \mathrm{PO}_{4}, \mathrm{NaCl}$ (Ramin et al., 2008, modifikasi), jerami padi, dan susu bubuk. Bakteri Actinobacillus sp. yang digunakan merupakan hasil temuan Mirni et al. (2006).

Media alternatif dipanaskan sampai suhu 100 ${ }^{\circ} \mathrm{C}$ selama 5 menit. Setelah suhunya turun hingga mencapai suhu $40{ }^{\circ} \mathrm{C}$, media ditambahkan bakteri Actinobacillus sp. serta dijaga agar suhunya konstan selama 24 jam. Bakteri hasil biakan selanjutnya digunakan untuk memfermentasi ransum ruminansia.

Perlakuan yang diberikan pada ransum ruminansia terdiri atas 2 faktor. Faktor I berupa dosis enzim, terdiri atas 4 dosis, yaitu $0 \%(\mathrm{~K}), 2 \%(\mathrm{~A}), 3,5 \%(\mathrm{~B})$ and $5 \%$ (C) sedangkan faktor II berupa lama waktu inkubasi enzim pada sampel, terdiri atas 2 waktu, yaitu 3 hari dan 7 hari. Masing-masing perlakuan diulang sebanyak 4 kali. Setelah masa inkubasi selesai, sampel dibuka kemudian dianalisis kandungan nutrisinya. Parameter pengamatan berupa kandungan bahan kering, bahan organik, protein kasar, dan kandungan serat kasar (AOAC, 1980).

Data yang diperoleh dianalisis menggunakan Analisis Varian dengan Rancangan Acak Lengkap pola Faktorial (2 faktor) dengan 4 ulangan. Jika terdapat perbedaan yang nyata antar perlakuan, maka diuji dengan Duncan's Multiple Range Test (Gill, 1981).

\section{HASIL}

Hasil penelitian menunjukkan bahwa fermentasi ransum ruminansia menggunakan bakteri Actinobacillus sp. selama 3 hari menggunakan dosis $2 \% ; 3,5 \%$ maupun $5 \%$ secara nyata dapat meningkatkan kandungan bahan kering dibandingkan kontrol, namun pada hari ke-7 terjadi penurunan kandungan bahan organik dibandingkan dengan pada hari ke-3, meskipun masih lebih tinggi dibandingkan dengan kontrol seperti terlihat pada Tabel 1 .

Tabel 1 Kandungan Bahan Kering Ransum Ruminansia (\%) yang Difermentasi dengan Beberapa Dosis dan Waktu Inkubasi.

\begin{tabular}{cccccc}
\hline \multirow{2}{*}{$\begin{array}{c}\text { Waktu } \\
\text { Inkubasi }\end{array}$} & \multicolumn{4}{c}{ Dosis Fermentasi } & \multirow{2}{*}{ Rataan } \\
\cline { 2 - 5 } 3 hari & $97.44 \pm 0.06^{\mathrm{d}}$ & $\mathbf{2 \%}$ & $\mathbf{3 , 5 \%}$ & $\mathbf{5 \%}$ & \\
\hline 7 hari & $97.58 \pm 0.08^{\mathrm{cd}}$ & $97.55 \pm 0.19^{\mathrm{a}}$ & $98.44 \pm 0.24^{\mathrm{a}}$ & $98.57 \pm 0.32^{\mathrm{a}}$ & $98.23 \pm 0.59$ \\
Rataan & $97.51 \pm 0.11$ & $98.00 \pm 0.65$ & $98.13 \pm 0.45$ & $98.30 \pm 0.38$ & \\
\end{tabular}

a,b) Notasi berbeda pada baris dan kolom yang sama menunjukkan perbedaan nyata $(\mathrm{P}<0,05)$. 
14 | Al-Arif \& Lamid

Tabel 2 Kandungan Bahan Organik Ransum Ruminansia (\%) yang Difermentasi dengan Beberapa Dosis dan Waktu Inkubasi.

\begin{tabular}{|c|c|c|c|c|c|}
\hline \multirow{2}{*}{$\begin{array}{l}\text { Waktu } \\
\text { Inkubasi }\end{array}$} & \multicolumn{4}{|c|}{ Dosis Fermentasi } & \multirow{2}{*}{ Rataan } \\
\hline & $0 \%$ & $2 \%$ & $3,5 \%$ & $5 \%$ & \\
\hline 3 hari & $84.92 \pm 0.51^{d}$ & $86.04 \pm 0.52^{\mathrm{bc}}$ & $86.33 \pm 0.80^{b c}$ & $85.41 \pm 0.80^{c d}$ & $85.68 \pm 0.75$ \\
\hline 7 hari & $85.78 \pm 0.56^{c d}$ & $86.98 \pm 0.85^{a b}$ & $87.04 \pm 0.45^{\mathrm{ab}}$ & $88.04 \pm 0.61^{\mathrm{a}}$ & $86.96 \pm 0.72$ \\
\hline Rataan & $85.35 \pm 0.61$ & $86.51 \pm 0.67$ & $86.69 \pm 0.50$ & $86.73 \pm 1.86$ & \\
\hline
\end{tabular}

a,b) Notasi berbeda pada baris dan kolom yang sama menunjukkan perbedaan nyata $(P<0,05)$.

Tabel 3 Kandungan Protein Kasar Ransum Ruminansia (\%) yang Difermentasi dengan Beberapa Dosis dan Waktu Inkubasi.

\begin{tabular}{|c|c|c|c|c|c|}
\hline \multirow{2}{*}{$\begin{array}{l}\text { Waktu } \\
\text { Inkubasi }\end{array}$} & \multicolumn{4}{|c|}{ Dosis Fermentasi } & \multirow{2}{*}{ Rataan } \\
\hline & $0 \%$ & $2 \%$ & $3,5 \%$ & $5 \%$ & \\
\hline 3 hari & $12.58 \pm 0.10^{b}$ & $12.89 \pm 0.24^{b}$ & $13.82 \pm 0.32^{\mathrm{a}}$ & $13.01 \pm 0.51^{b}$ & $13.07 \pm 0.65$ \\
\hline 7 hari & $12.90 \pm 0.02^{\mathrm{b}}$ & $13.88 \pm 0.40^{\mathrm{a}}$ & $13.96 \pm 0.35^{a}$ & $13.95 \pm 0.32^{\mathrm{a}}$ & $13.67 \pm 0.60$ \\
\hline Rataan & $12.74 \pm 0.23$ & $13.38 \pm 0.71$ & $13.89 \pm 0.10$ & $13.48 \pm 0.67$ & \\
\hline
\end{tabular}

a,b) Notasi berbeda pada baris dan kolom yang sama menunjukkan perbedaan nyata $(P<0,05)$.

Tabel 4 Kandungan Serat Kasar Ransum Ruminansia (\%) yang Difermentasi dengan Beberapa Dosis dan Waktu Inkubasi.

\begin{tabular}{|c|c|c|c|c|c|}
\hline \multirow{2}{*}{$\begin{array}{l}\text { Waktu } \\
\text { Inkubasi }\end{array}$} & \multicolumn{4}{|c|}{ Dosis Fermentasi } & \multirow{2}{*}{ Rataan } \\
\hline & $0 \%$ & $2 \%$ & $3,5 \%$ & $5 \%$ & \\
\hline 3 hari & $29.78 \pm 0.21$ & $27.16 \pm 0.67$ & $26.81 \pm 0.96$ & $24.35 \pm 1.13$ & $27.03 \pm 2.23^{a}$ \\
\hline 7 hari & $29.19 \pm 0.08$ & $26.04 \pm 0.85$ & $26.38 \pm 1.08$ & $23.14 \pm 0.63$ & $26.19 \pm 2.48^{b}$ \\
\hline Rataan & $29.49 \pm 0.08^{a}$ & $26.60 \pm 0.85^{b}$ & $26.59 \pm 1.08^{b}$ & $23.74 \pm 0.63^{c}$ & \\
\hline
\end{tabular}

a,b) Notasi berbeda pada baris dan kolom yang sama menunjukkan perbedaan nyata $(P<0,05)$.

Fermentasi ransum ruminansia menggunakan bakteri selulolitik dengan dosis 2\%; 3,5\% maupun 5\% yang diinkubasi selama 3 hari secara nyata dapat meningkatkan kadar bahan organik. Pada hari ke-7 peningkatan bahan organik semakin nyata seperti terlihat pada Tabel 2.

Fermentasi ransum ruminansia menggunakan bakteri selulolitik pada hari ke-3 hanya pada dosis $3,5 \%$ saja yang terjadi peningkatan protein kasar, sedangkan pada hari ke-7 terjadi peningkatan protein kasar pada semua dosis, baik 2\%; 3,5\% maupun $5 \%$, seperti terlihat pada Tabel 3.

Kandungan serat kasar ransum ruminansia menurun secara nyata pada hari ke-7 dibandingkan dengan pada hari ke-3, sedangkan dosis fermentasi juga mempengaruhi penurunan serat kasar, meskipun tidak terdapat interaksi antara dosis fermenta- si dan masa inkubasi. Penurunan serat kasar paling banyak terjadi pada penggunaan dosis $5 \%$, seperti terlihat pada Tabel 4.

\section{PEMBAHASAN}

Kenaikan kadar bahan kering ransum ruminansia yang difermentasi menggunakan bakteri selulolitik selama 3 hari disebabkan adanya perkembangbiakan bakteri dalam ransum ruminansia, sedangkan penurunan kadar bahan kering pada inkubasi 7 hari disebabkan adanya proses degradasi serat kasar sehingga konsentrasinya menurun. Serat kasar merupakan bagian dari bahan kering, sehingga penurunan serat kasar juga berpengaruh pada penurunan bahan kering. Degradasi serat kasar menghasilkan $\mathrm{CO}_{2}$ dan $\mathrm{H}_{2} \mathrm{O}$, hal ini juga ber- 
pengaruh pada penurunan kandungan bahan kering karena adanya penambahan air. Kadar bahan kering pada perlakuan B (3,5\%) dan C (5\%) yang diinkubasi selama 7 hari masih lebih tinggi dibandingkan dengan kontrol, hal ini disebabkan penurunan bahan kering karena adanya degradasi serat kasar masih diimbangi dengan perkembangbiakan bakteri selulolitik.

Peningkatan kadar bahan organik bisa disebabkan oleh adanya peningkatan protein kasar akibat adanya perkembangbiakan bakteri selulolitik. Protein kasar merupakan bagian dari bahan organik sehingga adanya peningkatan protein kasar juga dapat menyebabkan peningkatan bahan organik. Kandungan bahan organik juga dipengaruhi kadar abu atau mineral. Jika kadar abu meningkat, maka bahan organik mengalami penurunan, begitu juga sebaliknya jika kadar abu menurun, maka bahan organik meningkat. El-Khier \& Al-Raheem (2011) menyatakan bahwa sorghum yang difermentasi dapat menyebabkan penurunan kandungan abu dengan semakin meningkatnya masa inkubasi. Haddadin et al. (2009) menyebutkan bahwa perubahan kandungan abu substrat selama proses fermentasi disebabkan oleh adanya perubahan bahan organik yang terjadi selama proses biokonversi.

Peningkatan kandungan protein kasar disebabkan adanya perkembangbiakan bakteri pada ransum ruminansia. Bakteri mengandung protein kasar $60 \%$ (Moran, 2005), oleh sebab itu adanya perkembangbiakan bakteri pada ransum ruminansia akan meningkatkan kandungan protein kasar ransum tersebut. Ransum ruminansia dapat digunakan sebagai sumber nutrisi bagi bakteri selulolitik sehingga memungkinkan untuk berkembangbiak.

Peningkatan protein kasar bisa juga disebabkan adanya penurunan kandungan serat kasar. Proses fermentasi dapat menghasilkan produk samping berupa $\mathrm{CO}_{2}$ dan $\mathrm{H}_{2} \mathrm{O}$ sehingga degradasi selulosa (polisakarida) yang merupakan bagian dari serat kasar menjadi oligosakarida atau monosakarida akan terjadi penurunan jumlah sakarida (karbohidrat) sehingga persentase protein kasar akan mengalami peningkatan.

Penurunan serat kasar disebabkan adanya degradasi polisakarida menjadi karbohidrat yang lebih sederhana. Semakin tinggi jumlah bakteri selulolitik, semakin banyak pula polisakarida yang terdegradasi sehingga penurunan serat kasar juga semakin tinggi. Dalam penelitian ini dosis $5 \% \mathrm{me}$ rupakan dosis optimum untuk menurunkan kandungan serat kasar ransum ruminansia. Dinding sel tanaman merupakan suatu struktur kimiawi yang kompleks, terdiri atas selulosa, hemiselulosa, pektin, dan lignin (Saha, 2004). Hidrolisis selulosa akan menurunkan jumlah selulosa yang merupakan bagian dari serat kasar sehingga fermentasi jerami padi yang banyak mengandung selulosa dapat menurunkan kandungan serat kasar.

Kesimpulan penelitian ini adalah bakteri seluIolitik Actinobacillus sp. yang dikembangbiakkan menggunakan media alternatif skala masal, efektif mendegradasi serat kasar pada ransum ruminansia. Penggunaan dosis $2 \% ; 3,5 \%$ dan $5 \%$ dengan waktu inkubasi 7 hari secara signifikan meningkatkan kandungan bahan organik dan protein kasar, serta menurunkan serat kasar, sedangkan dosis 3,5\% dan $5 \%$ dengan waktu inkubasi 7 hari secara signifikan juga meningkatkan kandungan bahan kering ransum ruminansia.

\section{UCAPAN TERIMA KASIH}

Terima kasih disampaikan kepada Dirjen Dikti yang telah mendanai penelitian ini melalui proyek penelitian Fundamental (2011-2012).

"Penulis menyatakan tidak ada konflik kepentingan dengan pihak-pihak yang terkait dalam penelitian ini."

\section{DAFTAR PUSTAKA}

Al-Arif MA, Lamid M. 2011. Produksi enzim selulase oleh Actinobacillus sp. menggunakan beberapa sumber nitrogen dalam media pertumbuhan alternatif. Majalah Kedokteran Hewan 7(2): 127131.

Bhat MK, Hazlewood GP. 2001. Enzymology and Other Characteristics of Cellulases and Xylanases. In: Enzymes in Farm Animal Nutrition. Bedford MR, Partridge GG (Ed). CABI Publ. Wallingford. Oxon. UK. p11-60.

Breznak JA, Brune A. 1994. Role of microorganisms in the digestion of lignocellulose by termites. Annual Review of Entomology 39: 453-487.

Doi RH, Kosugi A. 2004. Cellulosomes: plant-cellwall degrading enzyme complexes. Microbiology 2: 541-551.

Lynd LR, Weimer PJ, Van ZyI WH, Pretorius IS. 2002. Microbial cellulose utilization: fundamentals and biotechnology. Microbiology and Molecular Biology Reviews 66: 506-577.

Makarim AK, Sumarno, Suyamto. 2007. Jerami padi, Pengelolaan dan Pemanfaatan. Pusat Penelitian dan Pengembangan Tanaman Pangan. Badan Penelitian dan Pengembangan Pertanian. Bogor. p53-58.

http://www.journal.ipb.ac.id/indeks.php/actavetindones 
Mirni L, Puspaningsih NNT, Chusniati S. 2006. Penggunaan bakteri xilanolitik asal rumen sebagai inokulum pada jerami padi sebagai upaya peningkatan mutu pakan ternak ruminansia. Lembaga Penelitian. Universitas Airlangga, Surabaya. p19-25.

Mishra BK, Pandey AK, Lata. 2007. Lignocellulolytic enzyme production from submerged fermentation of paddy straw. Indian Journal of Microbiology 47: 176-179.

Moran J. 2005. Tropical Dairy Farming: Feeding Management for Small Holder Dairy Farmers in the Humid Tropics. Landlinks Press. Collingwood, Australia. p41-63.

Qi B, Yao R, Yu Y, Chen Y. 2008. Influence of different ratios of rice straw to wheat bran on production of cellulolytic enzymes by Trichoderma viride $\mathrm{ZY}-01$ in solid state fermentation. Electronic Journal of Environmental, Agricultural and Food Chemistry 7(9): 3239-3247.

Ramin M, Alimon AR, Sijam K, Abdullah N. 2008. Filter paper degradation by bacteria isolated from local termite gut. Research Journal of Microbiology 3(8): 565-568.
Saha BC. 2004. Lignocellulose Biodegradation and Applications in Biotechnology. In: Lignocellulose Biodegradation. Saha BC, Hayashi K (Ed.). American Chemical Society, Washington DC. p2-34.

Singh R, Kumar R, Bishnoi K, Bhatia D, Bishnoi NR. 2009. Rice straw (Lignocellulosic biomass) a novel substrat for cellulase production. Proceeding of International Conference on Energy and Environment. March, p19-21.

Wang NS. 2004. Cellulose Degradation. Biochemical Engineering Laboratory (ENCH 485). University of Maryland. http://www.eng.umd.edu/ nsw/ ench485/lab4.htm Download: May 3, 2011.

Yeoman CJ, Han Y, Dodd D, Schroeder CM, Mackie RI, Cann IKO. 2010. Thermostable enzymes as biocatalyst in the biofuel industry. Advances in Applied Microbiology 70: 1-55.

Zhang $H$, Hanada S, Shigematsu T, Shibuya K, Kamagata Y, Kanagawa T, Kurane R. 2000. Burkholderia kururiensis sp. nov., a trichloroethylene (TCE)-degrading bacterium isolated from an aquifer polluted with TCE. International Journal of Systematic and Evolutionary Microbiology 50: $743-749$. 